\title{
Effect of Some Yogic Practices on Aggression Level among College Girls
}

\author{
Pammi Singh ${ }^{1}$
}

\section{ABSTRACT}

This study was aimed at examining the effect of some yogic practices (Surya Namaskar, Anulom-Vilom Pranayama) on aggression level of adolescents. For this, 30 adolescents were conveniently selected from Dev Sanskriti University, Haridwar who were studying B.A. And B.Sc. First year 2015 and were randomly assigned into experimental groups. Yogic practice was allowed among participants for 25 days (from 15-Feb-10 March 2015). Measurement of pre and post logical memory of participants was made by using aggression Scale developed by $\mathrm{Km}$. Roma Pal. Result showed statistically significant decrease (89.13-73.26, observed t- value = 9.62) in post anxiety level of participants on 0.01 level of significance.

Keywords: Anulom-Vilom Pranayama, Surya Namaskara, aggression

The world Health Organization defines adolescence as the period of life between 10 and 19 years of age (www.wikipedia.com). Adolescence (Adolescence=to grow) is a transitional stage of physical and mental human development that occurs between childhood and adulthood.

Adolescence is a rapid period of rapid body growth and psychological development marked by a strong trend towards individuation in other words, the process of defining one's say as on individual.

Adolescence is a risky period opportunities for developing a wide variety of psychophysiology logical problems. (Erikson 1963). Adolescence is the period of physical, cognitive, social and emotional development. Teenager's experiences a period of relatively drastic social and biological and adulthood, it only stands to reason that teen stress would take on a unique character corresponding to the specific changes experienced during that period.

One pole of the adolescent crisis is identity. Identity means an integration of all previous identification and say images; including the negative ones (Erikson quoted in even 1976 p.279). Continuity is an important term in the conception of identity. Identity problems for teens are in part of related to their historical era In some cases it is seen that adolescence is a period of stress and unhappiness. Adolescence is the age in which several physical as wall as emotional changes,

\footnotetext{
${ }^{1}$ Research Scholar, yoga Dept. Mahatma Gandhi Chitrakoot Groamodaya University Chitrakoot, Satna, MP (C) 2015 I P Singh; licensee IJIP. This is an Open Access Research distributed under the terms of the Creative Commons Attribution License (http://creativecommons.org/licenses/by/2.0), which permits unrestricted use, distribution, and reproduction in any Medium, provided the original work is properly cited.
} 


\section{Effect of Some Yogic Practices on Aggression Level among College Girls}

cognitive changes take place this is the age for the child to snap and to form a good personality. These changes may guide or even misguide them to develop behavior.

Yoga practices enhance the creative power of adolescents. Yoga offers a find tool for the development of the emotional personality adolescents.

Yoga practices like Surya Namaskar and Anulom-Vilom Pranayama can bring comprehensive development to the intellect.

Surya Namaskar is the combination of asana and pranayama. It maintains physical as well as emotional state of person. During adolescence period it is so good practice because it maintains hormonal changes and uncontrolled emotions.

Dr. Crisan (1980) studied the effect of 4 weeks of pranayama practice in 19 cases of carefully diagnosed cases of general anxiety and showed statistically significant reduction in their anxiety scores, pulse rate and BP.

Anulom-Vilom is very powerful pranayama. Through this pranayama one can control very sharply his body and mind. Physical activities play an important role in the management of mild to moderate mental health diseases especially frustration, aggression and anxiety. This yogic package Namaskara \& Anulom-Vilom pranayama is very helpful to maintain peace, clam, and pleasant mind.

\section{REVIEW OF LITERATURE}

Joshi, B.P. (2003):- The present work is aimed to study of Kapalbhati, Vaman and Bhramari pranayama on college going students (age group 18-25 years) of J.S. Sanskrit Mahavidyalaya, Saptrishi ashrama, Haridwar. Total sample were 40 males. by statistical analysis it has been observed that there is a significant relationship between the practice of Kapalbhati, Vaman and Bhramari and Hemoglobin, E.S.R., F.V.C., physical and mental health. All the psychological and physiological tests were measured in Brahmavarchas research centre, Shanti kunj, Haridwar.

Nandi. S.A.H. \& Bera. T.K. (2003): Reported the effect of selected aerobic exercise and yogic practices or the effect of both on cardio-respiratory endurance. 80 school boys $\left(9^{\text {th }}\right.$ and $\left.10^{\text {th }}\right)$ were randomly selected and then subdivided into 4 equal groups ( $\mathrm{n}=20$ in each group). Three training programs viz, aerobic exercise, yogic practice and combination of aerobic exercise and yogic practice, were randomly allotted to 3 groups, where the remaining one group studied as control. The performances on cooper's test (12 minutes Run-walk) of all the groups were recorded before and after the 12 weeks training programs. Result reveals that aerobic exercise group showed greater cardio-respiratory endurance ability.

Pathak, S. (2006):- The aim of the present investigation is to study the effect of Navdivasiya sadhana satra on anxiety, depression and guilt. The sample consists of 60 males and females which was taken by quota sampling. The results show that navdivasiya sadhana satra, its 


\section{Effect of Some Yogic Practices on Aggression Level among College Girls}

programme and the ecology of Shantikunj significantly reduces the level of anxiety and depression.

Singh, V. (2008):- The aim of this research study was to observe the effect of Anulom-Vilom pranayama on blood $\mathrm{Hb}$ of the subjects with the age 20-40 years. For this 40 subjects composed of 20 male and 20 female were drown from Yug-Shilpi training participants on Shantikunj, Haridwar in November, 2003 by using simple random sampling without replacement. Pre-post data were reported before and after intervention of Anulom-Vilom pranayama for 30 days by using sahil's haemometer. Calculated t-value 6.625, 7.665 and 23 for total, female and male subjects are significant at $\mathrm{P}<0.0025$ for $\mathrm{df} 39,19$ and 19 respectively. The result met concludes that Anulom-Vilom pranayama plays positive significant role to enhance blood $\mathrm{Hb}$ of the subjects.

Sharma, V. (2003):- She has conducted a project “Effect of Surya Namaskar on anxiety”. The result predicted that surya Namaskar effects significantly at the level 01.

\section{METHOD}

Research design:- pretest-posttest research design.

Sample \& Sampling:- In the present study, the researcher had used quota sampling the researcher has taken new admission girls of DSVV there ages were from 18-20 years.

Procedure:- The basic aim of taking new admission girls was simply that they to "Yogic Practices" on a daily basic. There are 30 subjects were taken into the practiced og yogic package (Surya namaskar \& Anulom-Vilom) for 25 days for the duration of $\mathbf{3 0}$ minutes per day in the morning time in 6.am to 6.30am. The data obtained from the pre and post test are statistically analyzed by using t-test.

The surya namaskar and pranayam "ANULOM-VILOM PRANAYAMA" the process of pranayam consist three phages PURAK, RECHAK \& KUMBHAK” l.e. called inhalation, exhalation.

\begin{tabular}{|lll|}
\hline Prayer & $:$ & Gayatri mantra, Guru vandana \\
Surya Namaskar & $:$ & 3 Round \\
Pranayama & $:$ & 3 Round \\
\hline
\end{tabular}

Tool: Aggression Scale Scaled by : Km. Roma Pal (1983)

Hypothesis: In this study directional Hypothesis is used.

There is significant effect of practice of yogic package on the level of aggression. 
RESULT TABLE

Statistical Analysis:- t-test has been used to analysis the results.

Mean

\begin{tabular}{|l|l|l|l|l|l|l|l|l|}
\hline Group & Mean & SD & SE $_{\mathbf{D}}$ & N & r & Df & T-value & $\begin{array}{l}\text { Level } \\
\text { significant }\end{array}$ \\
\hline Pre 89.13 & 2.48 & 1.65 & 30 & 0.76 & 29 & 9.62 & 0.01 & \\
\hline Post & 73.26 & 2.14 & & & & & & \\
\hline
\end{tabular}

\section{Graphical representation of Table}

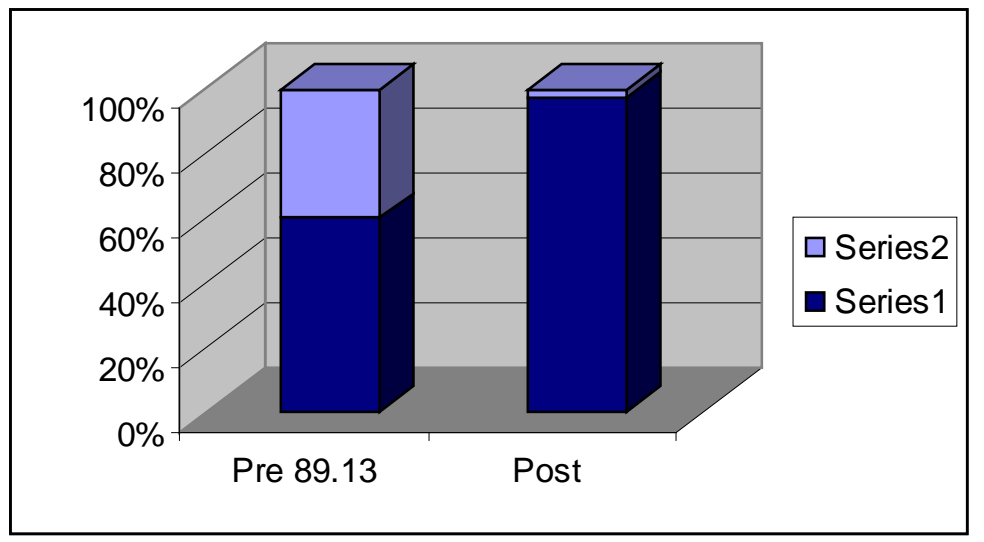

This it is found that the pre mean and post mean value of the group in 89.13 and 73.26 and the tvalue received is 9.62 which is significant at 0.01 level of significance.

\section{INTERPRETATION}

In the present study "The effect of some yogic practices on aggression level among adolescents" has significant effect.

Statistically it is found in table shows that level of aggression has significance difference among adolescents In the aggression scale scoring pattern indicates that there is high score means aggression is high and low score means low aggression. Subjects obtained high mean score89.13 in pretest and 73.26 mean score in post-test second hypotheses has been rejected at 0.01 levels that shows more difference in the level of aggression among adolescents. Graph shows clearly the aggression level. This study is applied on adolescents and their psychological aspects.

Adolescence is the period of physical, cognitive, social and emotional development. In this period changes occur such as physical, emotional as well as socially. They cannot express their feelings clearly. These changes show in their behavior. This behavior confects creates aggression and due to this type of behavior they loose their confidence.

Yoga is well known as it merges the mental meditation physical yoga practices and breathing exercise for deep relaxation of body and mind. (Tunny, J 2007) 


\section{Effect of Some Yogic Practices on Aggression Level among College Girls}

Yoga makes us feel better. Prating the postures breathing exercise make people healthier in body, mind and sprits Researches show that yoga helps to control anxiety, depression, stress, chromic fatigue, blood pressure and other conditions and disease.

In adolescence period during puberty immense changes and taking place in the body's chemistry and physiology Imbalance of body chemistry and physiology often show up in rebellion and mood swings. Nervous system is affected due these problems. So adolescent feel frustration and feel frustration and feel inferiority so they become aggressive and can not express them among society so they feel low confident. Yoga makes then free from all problems. By doing some yogic practice they can get rid of their problems either physical or psychological. Surya Namaskar is one of these yogic practices. It is the combination of postures as well as pranayama. it has twelve postures with breathing awareness. (Javalgekar, R. 1990)

Sharma Vinita (2003):- She has conducted a project "effect of Surya Namaskar on anxiety". The result practiced that Surya Namskar effects significantly at the level 0.01.

Above research shows that Surya namaskar releases anxiety. So person can get rid of anxiety. it well increase their awareness and their ability to look within, think for themselves, and trust themselves. The result that they will feel move peaceful during a period of rapid change and be able to engage the world with a move positive outlook.

\section{CONCLUSION}

It is therefore concluded, with the limitations of this study, that the intensive practice of yoga package (Surya Namaskar \& Anulom-Vilom Pranayama) showed significantly changes in the level of aggression among adolescents.

Statistically it is found that is significant difference in the level of aggression among adolescents. Some researches show that Surya Namaskar is a perfect combination of asana and pranayama. So it affects both as asana and pranayama. Anulom-Vilom is also very beneficial for physiological as well as psychological imbalances for adolescents.

Adolescence is a growing age and all types of development like physical, emotional and social occur in this period. After doing practices of this yoga package it is found that this is important yoga package for adolescent's asana makes their flexible and pranayama controls the emotions because this package regulates the nervous system. So in this research work it is found that if adolescent will continue this practice regularly, they will become strongly physically as well as emotionally. Yoga is the best way for living life for everyone.

joshi, B.P. (2003):- The present work is aimed to study of Kapalbhati, Vaman and Bhramari pranayama on college going students )age group 18-25 years) of J.S. Sanskrit Mahavidyalaya, Saptrishi Ashrama, Haridwar. Total sample were 40 males. By statistical analysis it has been observed that there is a significant relationship between the practice of Kapalbhati, Vaman and 


\section{Effect of Some Yogic Practices on Aggression Level among College Girls}

Bhramari and Hemoglobin, E.S.R., F.V.C., physical and mental health. All the psychological and physiological tests were measured in brahmavarchas research center, Shanti kunj, Haridwar.

Rai, G.C. (1991):- Investigated that the adjustment of more aggressive students was significantly less than that of less aggressive students, whose adjustment in turn was significantly less than that of non aggressive students.

Mandlik, V. (2007):- The present study was undertaken to observe critically the energy cost and different cardio respiratory changes during the practice of Surva Namaskar. Twenty one male voluntreers from the Indian army practiced selected for this study. Subjects performed Surya Namaskar for 3 min 40 second on an average. After three month training the result was significantly in cardio respiratory changes.

\section{REFERENCES}

Garrett, H.R. (2007), Statistics in Psychology and Education, Kalyani publication.

Javalgekar, R. (1990), Surya Namaskar The yoga science for everyone, Chaukhamba Sanskrit Sansthan, Varanasi.

Nagendra, H.R. Nagarthana (2008), Pranayama the art of science, Swami Vivekananda Yoga Prakashan, Banglore.

Singh, A.K. (2002), “Social psychology” motilal Banarasidas publication, Delhi.

\section{WEBSITES}

Crisan, H. (1980), Pranayama and Health, Retrived from www.adolescentshealth.com on 201002-19.

Javalgekar, R. (1990), Surya Namaskar, The yoga science for everyone, Chaukhambha Sanskrit Sansthan, Varanasi.

Jerard, P. (2007), Pranayama and Brain, Retrieved from www.healthandyoga.com on 2010-0216.

Joshi, B.P. (2003), Physiology and psychology effect of yogic pranayama practices, Retrieved from www.dsvv.org on 2010-03-03.

Mandlik, V. (2007), Energy cost and card respiratory changes during surya namaskar, Indian journal of psychology, Retrieved from www.dhritiwodrpress on 2010-02-20.

Surya Namaskar, The holistic core Retrieved from www.yogapoint.com on 2010-2015.

Tunney, J. (2007), Why do Yoga, Retrieved from www.yogahealth.com on 2010-01-25. 